\title{
BIOCHEMICAL AND MORPHOLOGICAL ANALYSIS OF CELL DEATH INDUCED BY EGYPTIAN COBRA (Naja haje) VENOM ON CULTURED CELLS
}

\author{
OMRAN M. A. A. ${ }^{1}$, FABB S. A. ${ }^{2}$, DICKSON G. ${ }^{2}$ \\ ${ }^{1}$ Zoology Department, Faculty of Science, Suez Canal University, Ismailia, Egypt; ${ }^{2}$ Centre for \\ Biomedical Sciences, School of Biological Sciences, Royal Holloway, Egham, Surrey, UK.
}

\begin{abstract}
We investigated the in vitro process of cell death caused by Egyptian cobra venom on primary human embryonic kidney (293T) and mouse myoblast (C2C12) cell lines. The aim of these studies was to provide further information about triggering cell death, and suggest methods for eliminating unwanted cells, such as tumour cells. Both cell lines were treated with 10, 20, and $50 \mu \mathrm{g} / \mathrm{ml}$ of Egyptian cobra (Naja haje) venom in serum free media (SFM) and incubated for 8 hours. Total activities of the lactate dehydrogenase (LDH) and creatine kinase $(\mathrm{CK})$ released in the culture during venom incubation were used as an indicator of the venom in vitro cytotoxicity. Cell injury was morphologically recognized and apoptosis determined by a Fluorescing Apoptosis Detection System and confirmed by staining nuclear DNA with DAPI. Our data clearly demonstrated marked cytotoxic effects and acute cell injury for both cell lines. Release of LDH and CK into the culture media induced by the venom correlates well with the morphological changes and extent of cell death. Mostly, these consequences were time and dose-dependent in both cell lines. The results obtained from this study indicated that cobra venom cause cell death by two different mechanisms: necrosis and induction of apoptosis. The apoptotic mechanism, accompanied by cell necrosis, mediated cell destruction of both tested cell lines; however, necrosis was predominant in the C2C12 cell line while apoptosis, in 293T cells. This unusual form of cell death induced by cobra venom may represent a combination of apoptosis and necrosis within the same cell. This is a first-hand investigation showing the apoptotic effects of $N$. haje venom at the cellular level. However, the contribution of the apoptotic pathway may be dependent on concentration and/or time of exposure to snake venom.
\end{abstract}

KEY WORDS: cobra venom, cytotoxicity, apoptosis.

\section{CORRESPONDENCE TO:}

M.A.A. Omran - Zoology Department, Faculty of Science, Suez Canal University, Ismailia, Egypt. Email: maomran@ismailia.ie-eg.com 
M. A. A. Omran et al. BIOCHEMICAL AND MORPHOLOGICAL ANALYSIS OF CELL DEATH INDUCED BY EGYPTIAN COBRA (Naja haje) VENOM ON CULTURED CELLS. J. Venom. Anim. Toxins incl. Trop. Dis., 2004, 10, 3, p.220.

\section{INTRODUCTION}

Cell death is caused by two primary processes: A) necrosis, in which the release of intracellular proteases and lysozymes induce an inflammatory response, or B) apoptosis, in which the cell remnants disappear as they are phagocytosed by surrounding cells (15). Cell death by necrosis usually follows a major acute pathological injury, such as hypoxia, hyperthermia, exposure to various exogenous toxins, or attack by complement. Necrosis is also characterized by early mitochondrial swelling and failure, followed by dysfunction of the plasma membrane with loss of homeostasis, cell swelling, and finally, rupture (30). On the other hand, Houchins (11) suggests that the major physiological mechanism of cell removal is apoptosis, in which cells are silently removed under normal conditions when they reach the end of their life span or are damaged by certain internal or external stimuli. Although the death signal may be regulated by gene expression, the process can be set in motion by diverse stimuli, such as genotoxic damage (chemotherapy and radiation), or cytokines deprivation (15).

Snakes are cold-blooded carnivorous vertebrates, and some species possess dangerous venoms. Cobras, which are widely distributed over the world, belong to the Elapidae family. Their venom contains a mixture of many different proteins, including a variety of enzymes (proteases and phospholipases), non-enzymatic polypeptide toxins (neurotoxins and cardiotoxins), and other substances $(33,34)$. Symptoms of snake envenoming result from combined effects of the complex protein components present in the venom. In severe cases, or at later stages of envenomation, tissue damage reaches many organs, such as the brain, lung, kidney, heart, and liver $(14,18,21,40)$. However, several studies have suggested the use of some venom components as therapeutic and anticancer agents, as well as in the production of recombinant neurotoxins $(16,36)$.

Clinically, the most common and important effect of Elapid envenomation in Africa is local tissue necrosis $(3,38)$. The mechanism of local necrosis resulting from Elapid venom may be different from that of the viper. Elapid venoms, generally, are not rich in enzymes, particularly proteases, thought to be responsible for the tissue damage that follows viper bites. African cobras bites produce necrotic effects that could be explained by the 60-70 amino acid 
M. A. A. Omran et al. BIOCHEMICAL AND MORPHOLOGICAL ANALYSIS OF CELL DEATH INDUCED BY EGYPTIAN COBRA (Naja haje) VENOM ON CULTURED CELLS. J. Venom. Anim. Toxins incl. Trop. Dis., 2004, 10, 3, p.221.

polypeptides, known as cytotoxins (or in some cases, cardiotoxins), and myotoxins, such as phospholipase $\mathrm{A}_{2}$. There is no clear correlation between the composition of Elapid venoms and the incidence of local necrosis after their bites; however, the injected venom dose may be an important variable (37).

Egyptian cobra, Naja haje, is widely distributed in Africa and the Middle East. The $\mathrm{LD}_{50}$ of its venom is $0.12 \mu \mathrm{g} / \mathrm{g}$ (19). Envenomation causes local pain and swelling, and may be associated with blistering at the bite site. Neurotoxic and systemic symptoms develop within few hours, and deaths have occurred within 6-16 hours after large snakes' bites, despite the use of antivenom and mechanical ventilation (38). Several authors have reported that sublethal doses of $N$. haje venom induced potent histopathological, histochemical, and pathophysiological alterations in the heart, liver, kidney, and brain of rats $(4,12,22-24)$. These pathological changes included severe degrees of cellular damage concomitant with marked signs of both myolytic and coagulative necrosis (27-29).

In vitro cell culture model systems and screening assays for cell death have become important tools to determine the chronology of events resulting in apoptosis. These systems have also proved to be useful in screening for inhibitory or stimulatory compounds that affect specific enzyme systems or the general process of cell death and apoptosis (20).

Despite the great advances in the understanding of morphological and biochemical alterations associated with chemical induced cell injury, the in vitro cytotoxic effects of cobra venom at the cellular level has not been well characterized. In this study, we analysed the type of cell death induced by Egyptian cobra venom on primary human embryonic kidney (293T) and mouse myoblast (C2C12) permanent cell lines at various time intervals, attempting to clarify the mode of action of the cytotoxic effects of this lethal venom.

\section{MATERIALS AND METHODS}

$N$. haje crude venom was milked from snakes collected from the El-Fayoum region in Egypt. The venom was rapidly frozen, lyophilised and kept in a dessicator at $4^{\circ} \mathrm{C}$ until used. 
M. A. A. Omran et al. BIOCHEMICAL AND MORPHOLOGICAL ANALYSIS OF CELL DEATH INDUCED BY EGYPTIAN COBRA (Naja haje) VENOM ON CULTURED CELLS. J. Venom. Anim. Toxins incl. Trop. Dis., 2004, 10, 3, p.222.

\section{Cell cultures}

293T and C2C12 cell lines were used in this study. 293T is a permanent line of primary human embryonic kidney cells, which has favourable tissue culture, transfection, and protein production properties (35). C2C12 is a subclone cell line derived from mouse myoblast cells from normal adult $\mathrm{C} 3 \mathrm{H}$ leg muscle. This cell line rapidly differentiates and produces extensive contracting myotubes expressing characteristic muscle proteins. It also provides an excellent model to study myogensis and cell differentiation in vitro (39). The cells were cultured in DMEM media (Sigma, St. Louis, MO, USA), supplemented with $10 \%$ heated inactive foetal bovine serum (FBS), 2mM L-glutamine, and the antibiotics penicillin (10,000units/L) and streptomycin (100-mg/L). Both cell lines were incubated as monolayers and cultured in plastic Falcon dishes (GIBCO, Grand Island, NY) at $37^{\circ} \mathrm{C} / 8 \% \mathrm{CO}_{2}$ in a fully humidified atmosphere.

\section{Biochemical analysis}

The cells used in this study were harvested by trypsinization ( $0.25 \%$ trypsin in PBS for 1 min), resuspended in fresh medium and plated in 24-well plates at $1.5 \times 10^{4}-2 \times 10^{5}$ cells/well. Both cell lines were incubated under the same conditions mentioned above. Different doses of cobra venom were prepared in serum free media (SFM), which was used to avoid a possible interaction between the venom and FBS. After 48 hours, the cultures were treated with various concentrations $(10,20$, and $50 \mu \mathrm{g} / \mathrm{ml}$ in SFM) of snake venom, and the cells were incubated for 8 hours. Toxicity was quantitatively assayed by measuring the activity of the cytosolic enzyme lactate dehydrogenase (LDH) released into the culture medium after membrane rupture. Samples from clarified medium of treated and untreated control wells (6 samples/treatment) were taken after 0.5, 1, 2, 4 and 8 hours of incubation, and the LDH activity was measured using the cytotoxicity assay CytoTox $96^{\circledR}$ (Promega, Madison, WI, USA) with a fully automated microplate reader photometer (HTIII, Anths Labtec Instruments, Salzburg). This assay system for quantifying the LDH released from cells can detect whether cell and apoptotic bodies remain enclosed by an intact plasma membrane, and thus, can be used to discriminate between apoptosis and necrosis (20). 
M. A. A. Omran et al. BIOCHEMICAL AND MORPHOLOGICAL ANALYSIS OF CELL DEATH INDUCED BY EGYPTIAN COBRA (Naja haje) VENOM ON CULTURED CELLS. J. Venom. Anim. Toxins incl. Trop. Dis., 2004, 10, 3, p.223.

Survival of the C2C12 cell line was ascertained by measuring the creatine kinase (CK) released into the culture media, which indicated muscle damage. CK was measured using Sigma Kit CK 47-UV; an assay based on the procedure described by Szasz et al. (32). The percentage of CK activity during cobra venom incubation was calculated according to the protocol described by Bruses et al. (2).

Morphological alterations and cell damage were qualitatively investigated using a light phase contrast microscope (Leica DMIRB, Germany), and the photos were taken at different time intervals by computerised Colour Coolview camera using the Image-Pro ${ }^{\circledR}$ Lite software (Media Cybernetics, Silver Spring, MD, USA).

\section{Venom stability in culture}

In order to test venom stability in the liquid medium, the culture containing cobra venom was incubated at $37^{\circ} \mathrm{C}$ in an $8 \% \mathrm{CO}_{2}$ fully humidified incubator. After different time intervals of incubation, samples of venom solution were taken and tested on C2C12 cells by measuring the activity of the CK released. The data obtained from this experiment indicated that cobra venom was stable during the incubation period ( $24 \mathrm{~h})$, and its cytotoxic effects on the selected cell line were marked.

\section{Apoptosis assays}

The C2C12 and 293T cells were cultured on lab-Tek chamber slides using the same culture medium as previously mentioned. Three days after reaching confluence, the cells were treated with various doses of snake venom (10, 20 and $50 \mu \mathrm{g} / \mathrm{ml}$ in SFM) and incubated for 1, 2, 4, and 8 hours. Chromatin condensation and/or nucleus fragmentation were morphologically investigated by DAPI (4', 6-diamidino-2-phenylindole dihydrochloride hydrate) staining (Sigma, St. Louis, MO, USA). Slides were stained with DAPI (dilution 1:1000 in PBS) for 10 minutes in the dark at $0-5^{\circ} \mathrm{C}$ and examined with a Leica DMIRB fluorescent microscope at 400X magnification using standard Fluorescein filter sets. Apoptotic cells were identified by their characteristic fragmented and condensed chromatin masses with fluorescent blue cytoplasm and pink to red nucleus $(5,31)$. Apoptotic cells were quantified by counting the number of apoptotic nuclei per number of total nuclei in the same microscopic field. The 
M. A. A. Omran et al. BIOCHEMICAL AND MORPHOLOGICAL ANALYSIS OF CELL DEATH INDUCED BY EGYPTIAN COBRA (Naja haje) VENOM ON CULTURED CELLS. J. Venom. Anim. Toxins incl. Trop. Dis., 2004, 10, 3, p.224.

apoptotic index was averaged for 5 fields showing the total of about 500 cells per treatment (31).

Nuclear DNA breaks were confirmed by the DNA nick end labelling (TUNEL) method. After the treatment, slides were washed 3 times with PBS and directly processed in the apoptosis detection assays. The assay used was a Fluorescein Apoptosis Detection System (Promega Madison, WI, USA), which is designed for specific detection and quantitation of apoptotic cells within a population of both apoptotic and non-apoptotic cells $(8,10,20)$. This system measures fragmented DNA of apoptotic cells by catalytically incorporating fluorescein-12dUTP at the 3-hydroxyl ends of the fragmented DNA using the enzyme Terminal deoxynucleotidyl Transferase (TdT), which forms a polymeric tail by the principle of the TUNEL (TdT-mediated dUTP Nick-End Labelling) method. When the enzymatic labelling procedure was completed, the slides were washed and the cells were counterstained with 1 $\mu \mathrm{g} / \mathrm{ml}$ propidium iodide (red at $620 \mathrm{~nm}$ ) for 15 minutes. The slides were mounted and photographed with a Leica DMIRB fluorescent microscope, and the dual exposure micrographs were recorded at 400X magnification using standard Fluorescein filter sets.

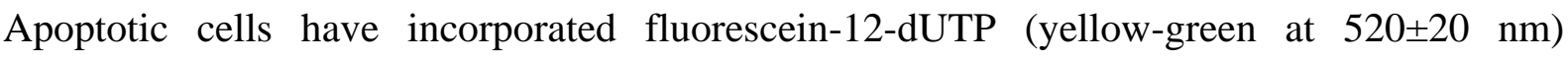
indicating the presence of DNA fragments.

\section{Statistical analysis}

Data represent the mean \pm SE of at least 5 replications. Statistical significance was tested by one way ANOVA and p-values inferior to 0.05 were considered significant.

\section{RESULTS}

\section{Biochemical analysis}

It is well documented that the in vitro release of LDH provides an accurate measure of cell membrane integrity and cell viability. Figure 1 shows the values of LDH released from the 293T cell line after 8 hours of incubation with cobra venom at concentrations ranging from 10 to $50 \mu \mathrm{g} / \mathrm{ml}$. The effect (\% LDH released) of the snake venom was dose and time-related. This effect was significant when compared to the control values after 4 and 8 hours at 
M. A. A. Omran et al. BIOCHEMICAL AND MORPHOLOGICAL ANALYSIS OF CELL DEATH INDUCED BY EGYPTIAN COBRA (Naja haje) VENOM ON CULTURED CELLS. J. Venom. Anim. Toxins incl. Trop. Dis., 2004, 10, 3, p. 225 .

$10 \mu \mathrm{g} / \mathrm{ml}$, and after 2, 4 and 8 hours at $20 \mu \mathrm{g} / \mathrm{ml}$. Although 10 and $20 \mu \mathrm{g} / \mathrm{ml}$ of Egyptian cobra toxin caused about $38-60 \%$ of $\mathrm{LDH}$ release respectively, $50 \mu \mathrm{g} / \mathrm{ml}$ released about $83 \%$ of LDH after 8 hours of incubation. The cytotoxic effect of the highest dose was significantly different to the control, as well as 10 and $20 \mu \mathrm{g} / \mathrm{ml}$ after 2, 4 and 8 hours.

$N$. haje venom produced significant release of cytosolic LDH into the culture medium at the different concentrations tested, compared to the control C2C12 cell line (Figure 2). This significant effect started 30 minutes after the incubation with 20 and $50 \mu \mathrm{g} / \mathrm{ml}$. At the highest concentration ( $50 \mu \mathrm{g} / \mathrm{ml}$ ), about $4 \%$ of the total LDH was retained by the cells after 8 hours of incubation with snake venom, while $56 \%$ and $70 \%$ was released by the same time after treatment with 10 and $20 \mu \mathrm{g} / \mathrm{ml}$, respectively. Thus, a clear difference between the toxic potency of cobra venom on the C2C12 and 293T cell lines was detected. As shown in Figure 2 , the contact time needed for cobra venom to induce a high value of LDH release ( $45 \%$ at 50 $\mu \mathrm{g} / \mathrm{ml}$ ) was extremely short (30 min).

In order to investigate the in vitro muscle toxicity, a similar experiment was performed with the $\mathrm{C} 2 \mathrm{C} 12$ cell line and CK activity in the medium (the presence of which indicates muscle injury). Figure 3 shows a dose-response effect of cobra venom on cultured C2C12 cells. A significant activity of CK released was recorded after 2, 4, and 8 hours of incubation with the lowest dose $(10 \mu \mathrm{g} / \mathrm{ml})$, compared to the untreated cells. However, this effect was observed as early as 1 hour and sustained up to the end of the experiment at a concentration of $20 \mu \mathrm{g} / \mathrm{ml}$. At the highest venom dose $(50 \mu \mathrm{g} / \mathrm{ml})$, significant levels of cytosolic CK were released after $0.5,1,2,4$, and 8 hours of incubation (38, 59, 65, 81, and 95\%, respectively). This effect was also statistically significant compared to the other doses (10 and $20 \mu \mathrm{g} / \mathrm{ml}$ ) after 2, 4, and 8 hours, accompanied by an increase in the number of spontaneous muscle twitches, especially after 1 and 2 hours of incubation.

\section{Morphological analysis}

Untreated 293T cells were homogeneously distributed in the culture field exhibiting a polygonal shape with distinct boundaries and homogenous or slightly granulated cellular contents (Figure 5A). However, after incubating this cell line with cobra venom for 8 hours, the occurrence of various morphological abnormalities was observed. At the lowest dose 
M. A. A. Omran et al. BIOCHEMICAL AND MORPHOLOGICAL ANALYSIS OF CELL DEATH INDUCED BY EGYPTIAN COBRA (Naja haje) VENOM ON CULTURED CELLS. J. Venom. Anim. Toxins incl. Trop. Dis., 2004, 10, 3, p.226.

$(10 \mu \mathrm{g} / \mathrm{ml})$, most of the cells lost their characteristic appearance and coalesced to such an extent, that individual cells could not be identified. These cells showed a syncitum-like appearance and an increase in the density of their cellular contents. Only few cells preserved their normal structure. In addition, some cellular swelling was observed, and areas devoid of any cultured cell appeared in-between the coalesced cells (Figure 5B). The incubation with 20 $\mu \mathrm{g} / \mathrm{ml}$ of cobra venom resulted in increased cell swelling and larger areas devoid of cells. In addition, other cells showed obvious deterioration and deformation, while some cells coalesced and lost their common structure (Figure 5C). At the highest venom concentration (50 $\mu \mathrm{g} / \mathrm{ml}$ ), the disappearance of normal morphological characteristics was very obvious (Figure 5D) with cells showing severe shrinkage and condensation of their cellular contents.

Morphological alterations induced by Egyptian cobra venom were also tested in C2C12 cells. Untreated cells were thin and elongated with two tapering ends (Figure 6A). The incubation with $10 \mu \mathrm{g}$ of cobra venom showed that C2C12 cells lost their common elongated shape and appeared in a form of numerous roughly rounded cells of variable size (Figure 6B). Areas devoid of cells were also recorded. After the incubation with $20 \mu \mathrm{g} / \mathrm{ml}$ of $N$. haje venom, the cells fragmented to minute vesicles. Few rounded cells and some areas devoid of cells were also noticed in the same culture medium (Figure 6C). The treatment with $50 \mu \mathrm{g} / \mathrm{ml}$ of venom led to the aggregation of dense irregular cellular debris. No intact cells were recognized in this medium, which indicates the occurrence of widespread cell death (Figure 6D).

\section{Venom apoptotic effect}

The in vitro apoptosis in 293T and C2C12 cell lines was analysed both qualitatively and quantitatively. Two techniques were used to detect the morphological changes in the apoptotic cells. The first is the Fluorescein Apoptosis Detection System, which uses a DNA nick-end labelling method (TUNEL) and detects DNA fragmentation associated to apoptotic process. In this assay, DNA fragments in apoptotic cells were labelled with green fluorescence, and background (non-apoptotic cells), counterstained with propidium iodide. The untreated control cells showed prevalence of red fluorescent cells, and no green-labelled cells were observed throughout the 8 hours of incubation (Figure 7: 1A, B and C). The incubation with $10 \mu \mathrm{g} / \mathrm{ml}$ of Naja haje venom demonstrated specific incorporation of 
M. A. A. Omran et al. BIOCHEMICAL AND MORPHOLOGICAL ANALYSIS OF CELL DEATH INDUCED BY EGYPTIAN COBRA (Naja haje) VENOM ON CULTURED CELLS. J. Venom. Anim. Toxins incl. Trop. Dis., 2004, 10, 3, p.227.

fluorescein-12-dUTP at the 3-hydroxyl ends of the fragmented DNA in most of the cultured cells, while few red cells were detected in the field after 2 hours (Figure 7: 2A). At the same dose, a time-dependent increase in the number of green-labelled cells (which reflects the number of apoptotic cells) was recorded (Figure 7: 2A, B and C). The treatment with 20 $\mu \mathrm{g} / \mathrm{ml}$ of cobra venom induced marked apoptosis after 2 hours (Figure 7: 3A), which increased after 4 hours (Figure 7: 3B), then significantly decreased after 8 hours of incubation (Figure 7: 3C). This might reflect the occurrence of another kind of cell death, such as necrosis and/or cell rupture following cell swelling as previously described. Similar results were obtained in the cultured cells incubated with the highest venom dose $(50 \mu \mathrm{g} / \mathrm{ml})$ showing increased number of apoptotic cells after 2 and 4 hours (Figure 7, 4A, B and C).

Apoptosis was also determined by DAPI staining, in which apoptosis is detected by chromatin condensation, nuclear fragmentation, or formation of apoptotic bodies. The cells incubated in SFM (control) showed a dominant blue fluorescence also found in normal non-apoptotic cells (Figure 8,1). DAPI staining of both cell lines after incubation with different concentrations of Egyptian cobra venom for 8 hours confirmed the previous results using the TUNEL technique, in which apoptosis was time and dose-related in the first 4 hours. Large to medium DNA fragments (considered a hallmark of apoptosis) with red fluorescent DAPI-positive nuclei are illustrated in Figure 8 (2-4).

Quantitative analysis of apoptotic indices was performed by counting the number of apoptotic cells after DAPI staining. Figure 4 (A and B) illustrates the in vitro apoptotic indices (\%) induced by Egyptian cobra venom in cultured cells. Generally, the increased number of apoptotic indices was time and dose-related in the first 4 hours of incubation in both cell lines; however, a marked reduction in this number was observed, especially at the highest concentration $(50 \mu \mathrm{g} / \mathrm{ml})$ of the venom after 8 hours of treatment. In 293T cells incubated with $10 \mu \mathrm{g} / \mathrm{ml}$ dose (Figure 4A), the apoptotic indices were increased from 18\% after 2 hours of incubation to $40 \%$ after 4 hours of incubation, then slightly increased to $45 \%$ after 8 hours of incubation. An additional increase (from $22 \%$ to $45 \%$ and $50 \%$ ) in the apoptotic cells was observed 2, 4 and 8 hours, respectively, after the treatment with $20 \mu \mathrm{g} / \mathrm{ml}$ of cobra venom. The highest percentages (28\% and 47\%) of apoptotic cells were recorded after 2 and 4 hours of incubation, respectively, with a $50 \mu \mathrm{g} / \mathrm{ml}$ dose, followed by a marked decline (30\%) after 8 
M. A. A. Omran et al. BIOCHEMICAL AND MORPHOLOGICAL ANALYSIS OF CELL DEATH INDUCED BY EGYPTIAN COBRA (Naja haje) VENOM ON CULTURED CELLS. J. Venom. Anim. Toxins incl. Trop. Dis., 2004, 10, 3, p.228.

hours (Figure 4A). Figure 4B shows that the cultured C2C12 cell line apoptotic indices caused by Egyptian cobra venom is, to some extent, different from those recorded in the 293T cell line, with $15 \%, 33 \%$, and $28 \%$ of apoptosis after 2, 4, and 8 hours of incubation, respectively, with a $10 \mu \mathrm{g} / \mathrm{ml}$ dose. Cells treated with $20 \mu \mathrm{g} / \mathrm{ml}$ of cobra toxin revealed an average percentage of apoptotic indices from $20 \%$ after 2 hours to $38 \%$ after 4 hours, which decreased to $25 \%$ after 8 hours. The lowest apoptotic indices (20\%) were observed after 8 hours of incubation with a $50 \mu \mathrm{g} / \mathrm{ml}$ dose.

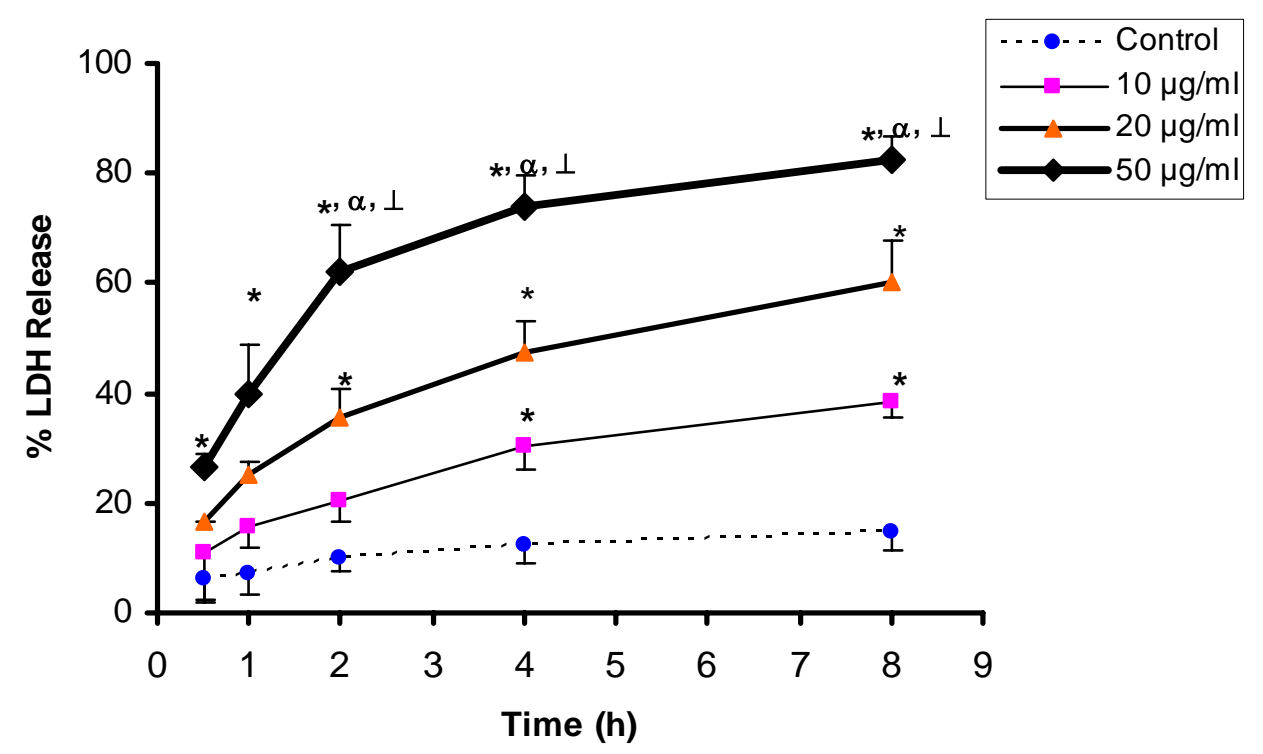

Figure 1. Cytotoxic effect of Egyptian cobra (Naja haje) venom on 293T cell line. Cultured permanent cell line (293T) of primary human embryonic kidney was incubated with 10, 20, and $50 \mu \mathrm{g} / \mathrm{ml}$ of cobra venom in serum free medium (SFM) for 8 hours at $37^{\circ} \mathrm{C}$. Total LDH released in the culture during venom incubation was used as an index of toxin induced cell damage. Control culture was treated with an equal amount of SFM. Values are means \pm S.E. (6 replicas/treatment). Data were analysed by one way ANOVA and $\mathrm{p}<0.05$ was considered significant

* Significantly different to untreated control cultures;

${ }^{\alpha}$ Significantly different to $10 \mu \mathrm{g} / \mathrm{ml}$ dose;

${ }^{\perp}$ Significantly different to $20 \mu \mathrm{g} / \mathrm{ml}$ dose. 


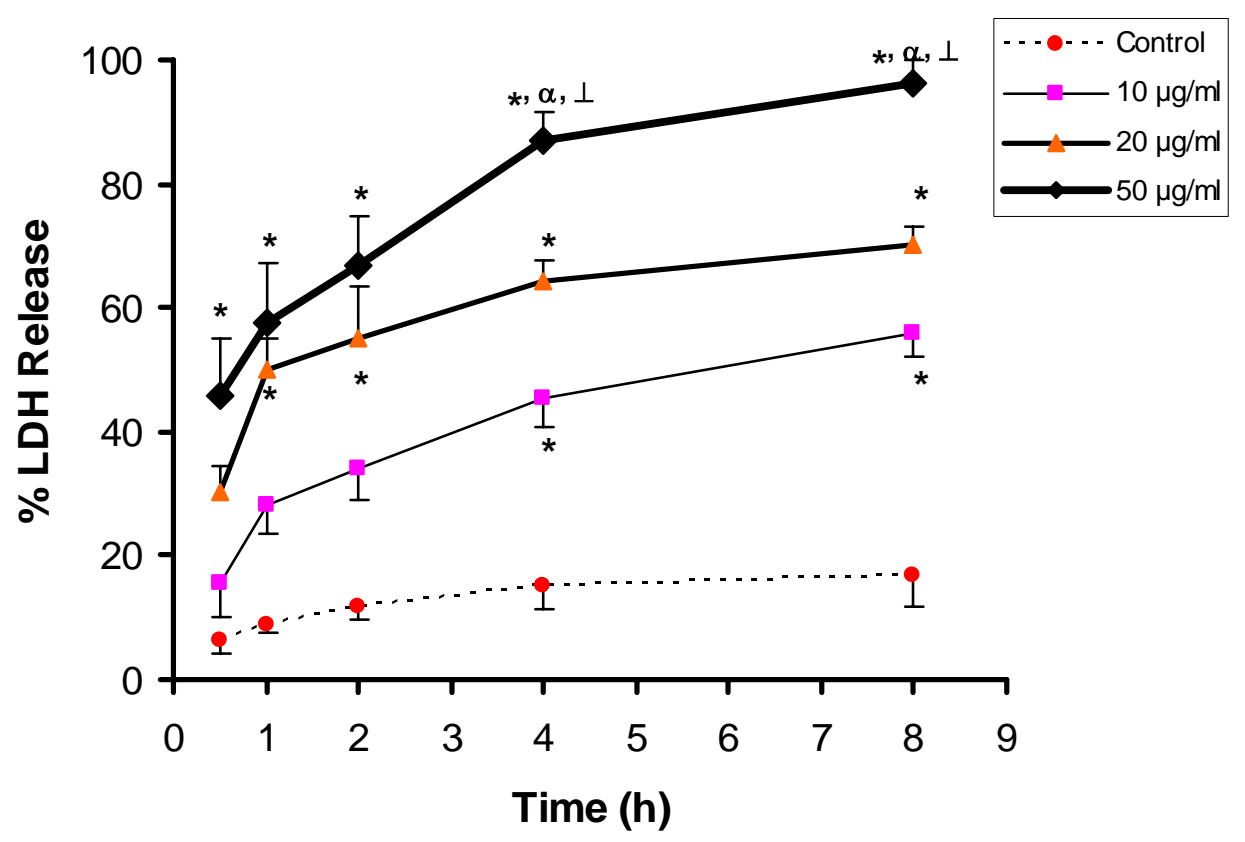

Figure 2. Cytotoxic effect of Egyptian cobra (Naja haje) venom on C2C12 cell line. Cultured fibroblasts from C2C12 cell line were incubated with 10, 20, and $50 \mu \mathrm{g} / \mathrm{ml}$ of cobra venom in serum free medium (SFM) for 8 hours at $37^{\circ} \mathrm{C}$. Total $\mathrm{LDH}$ released in the culture during venom incubation was used as an index of toxin induced cell damage. Control culture was treated with an equal amount of SFM. Values are means \pm S.E. (6 replicas/treatment). Data were analysed by one way ANOVA and $\mathrm{p}<0.05$ was considered significant

* Significantly different to untreated control cultures;

a Significantly different to $10 \mu \mathrm{g} / \mathrm{ml}$ dose;

${ }^{\perp}$ Significantly different to $20 \mu \mathrm{g} / \mathrm{ml}$ dose. 


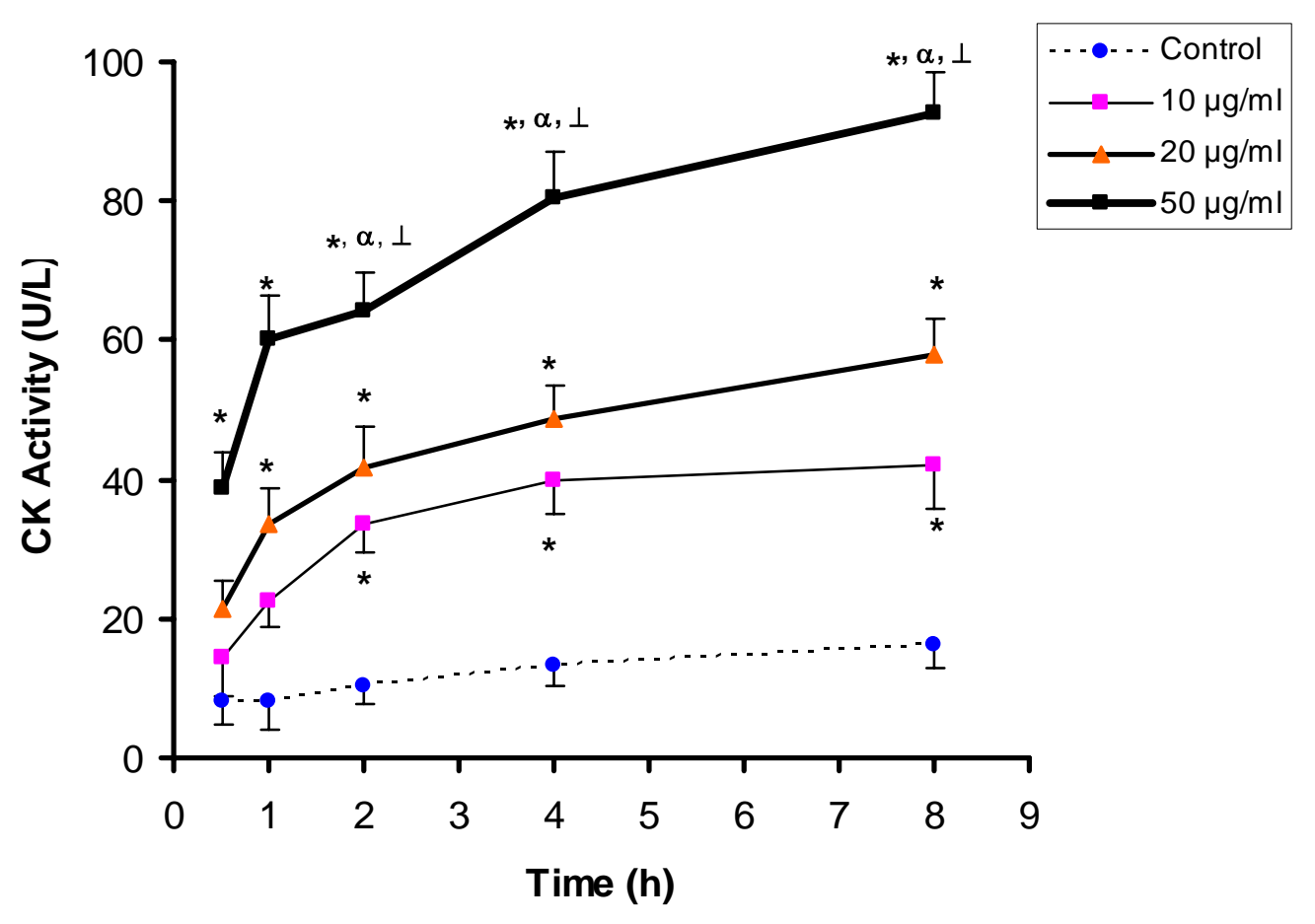

Figure 3. Cytotoxic effect of Egyptian cobra (Naja haje) venom on C2C12 cell line. Cultured fibroblasts from C2C12 cell line were incubated with 10, 20, and $50 \mu \mathrm{g} / \mathrm{ml}$ of cobra venom in serum free medium (SFM) for 8 hours at $37^{\circ} \mathrm{C}$. Total CK released in the culture during venom incubation was used as an indicator of the in vitro myotoxic activity of the venom. Control culture was treated with the same amount of SFM. Values are means \pm S.E. (6 replicas/treatment). Data were analysed by one way ANOVA and $\mathrm{p}<0.05$ was considered significant.

* Significantly different to untreated control cultures;

${ }^{\alpha}$ Significantly different to $10 \mu \mathrm{g} / \mathrm{ml}$ dose;

${ }^{\perp}$ Significantly different to $20 \mu \mathrm{g} / \mathrm{ml}$ dose. 

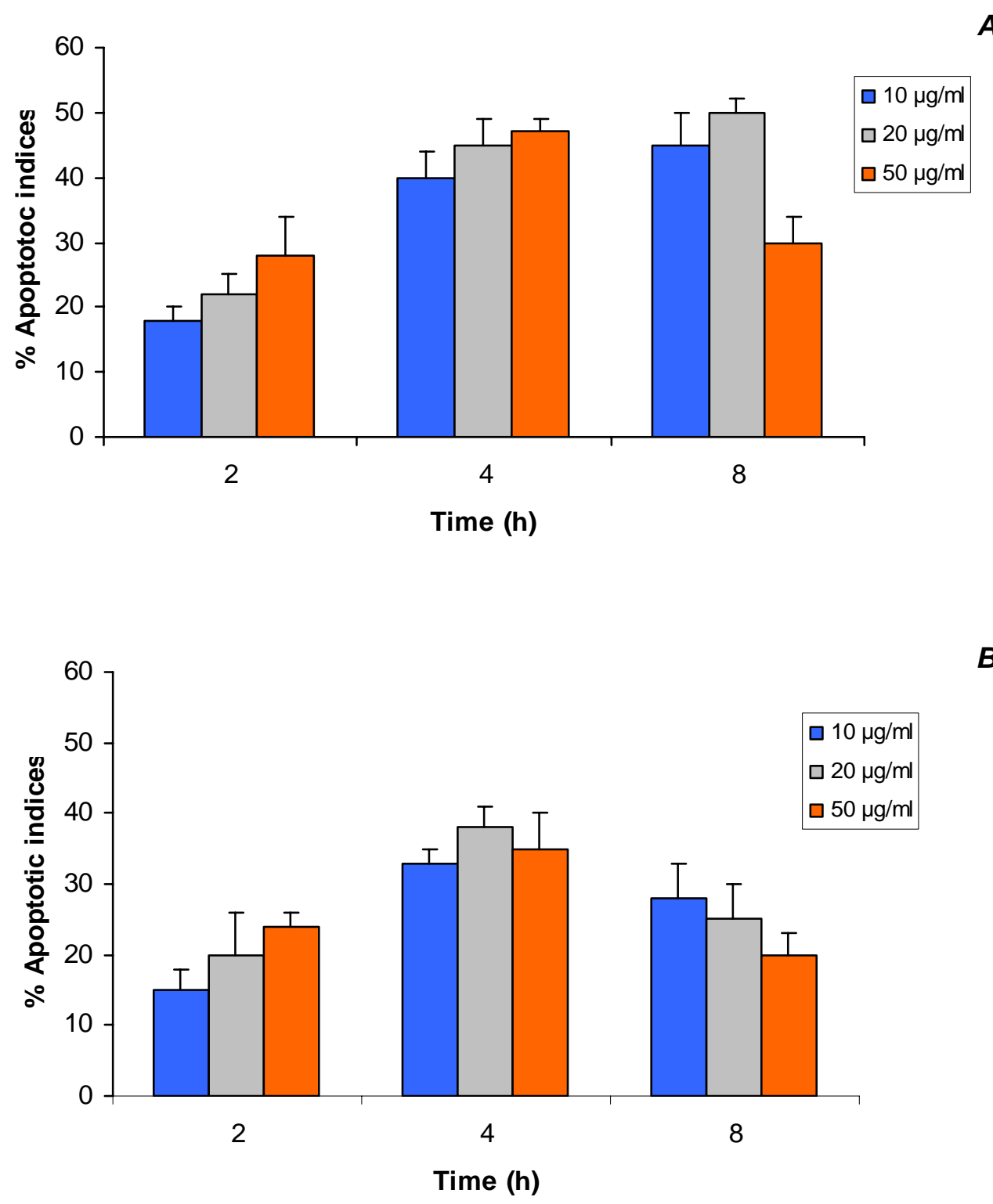

Figure 4. Effect of Egyptian cobra (Naja haje) venom on apoptotic indices of 293T cell line (A) and C2C12 cell line (B). Cultured cell lines were incubated with 10, 20, and $50 \mu \mathrm{g} / \mathrm{ml}$ of cobra venom in serum free medium (SFM) for 8 hours at $37^{\circ} \mathrm{C}$. Apoptotic indices were evaluated by DAPI-staining. Data are means \pm S.E. (at least 3 experiments). 

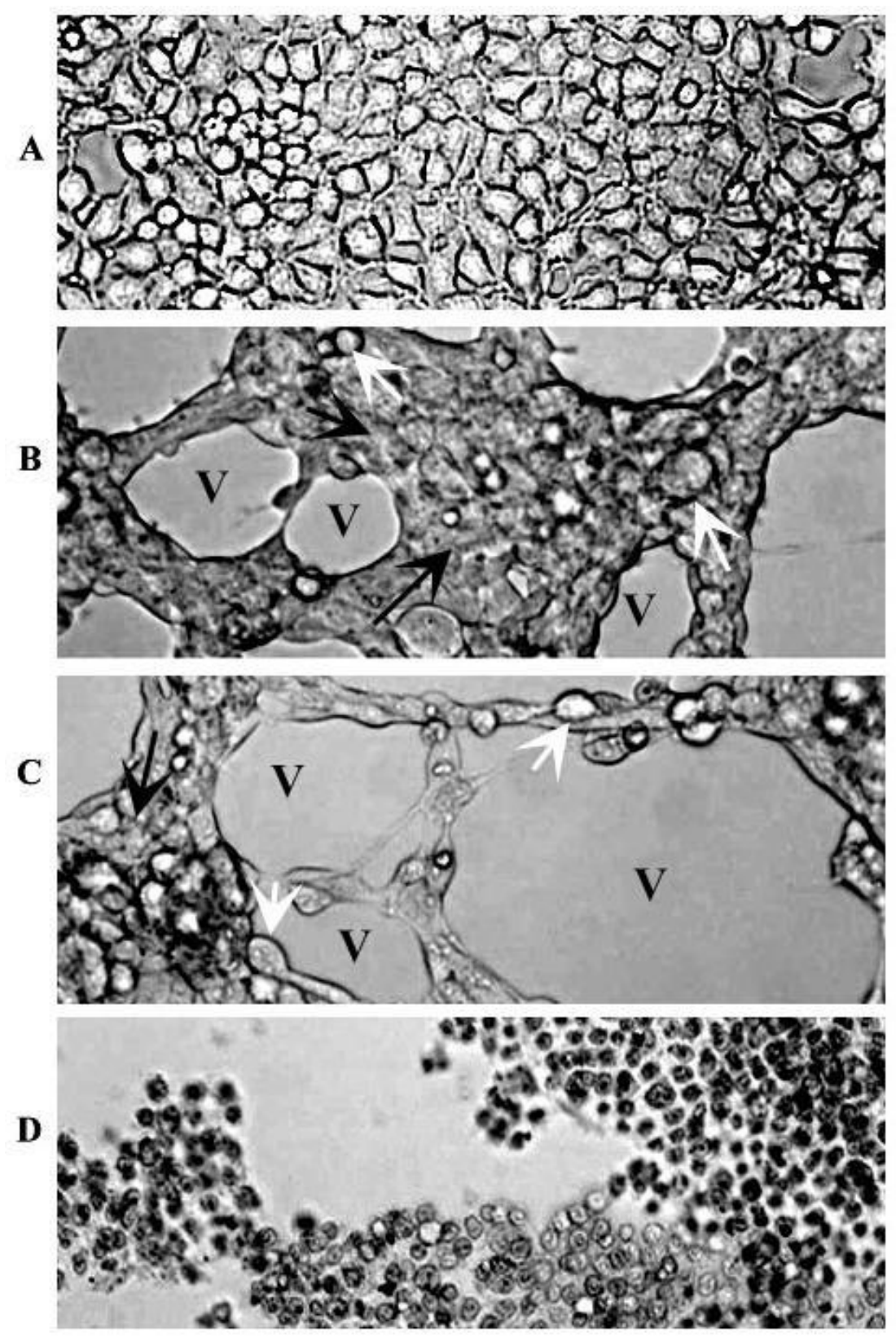

Figure 5. Light micrographs (phase contrast) of cultured permanent cell line (293T) of primary human embryonic kidney after 8 hours of incubation with 10, 20, and $50 \mu \mathrm{g} / \mathrm{ml}$ of Egyptian cobra (Naja haje) venom in serum free medium (SFM) at $37^{\circ} \mathrm{C}$. (X 400).

A: Untreated control cells were homogeneously distributed in the culture field. The cells exhibited polygonal shape with distinct boundaries and homogenous or slightly granulated cellular contents.

B: Cells incubated with $10 \mu \mathrm{g} / \mathrm{ml}$ dose. Note the occurrence of some cellular swelling (arrows) and presence of few vacuoles (V) devoid of any cultured cells.

C: Cellular swelling and the density of cellular contents were increased after incubation with 20 $\mu \mathrm{g} / \mathrm{ml}$ dose. Some cells were ruptured (black arrow) and lost the continuity of their surrounding membranes; the number of vacuoles (V) was also increased.

D: Cells incubated with the highest dose $(50 \mu \mathrm{g} / \mathrm{ml})$ of cobra venom. Note that the cells are highly damaged and cell debris were seen floating in the culture medium. 
A

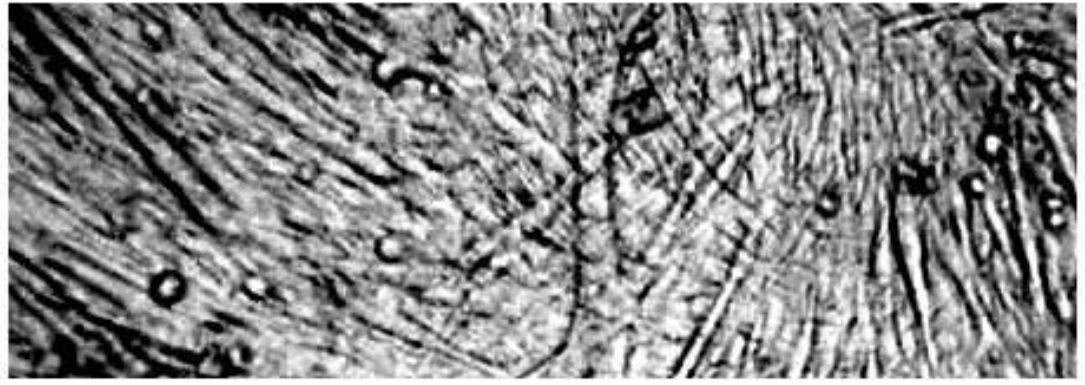

B

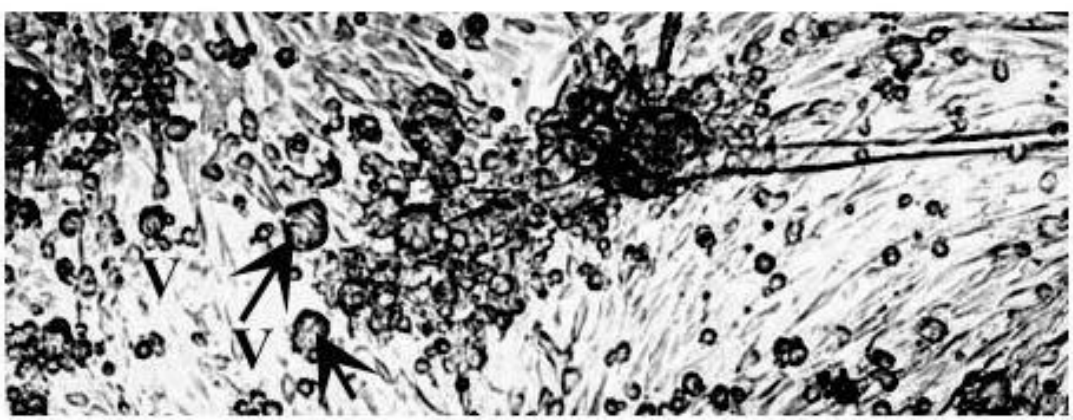

C

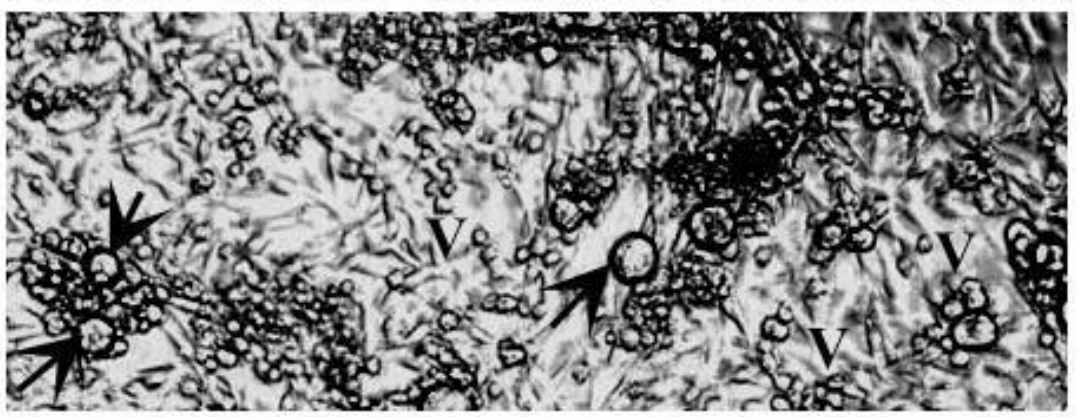

D

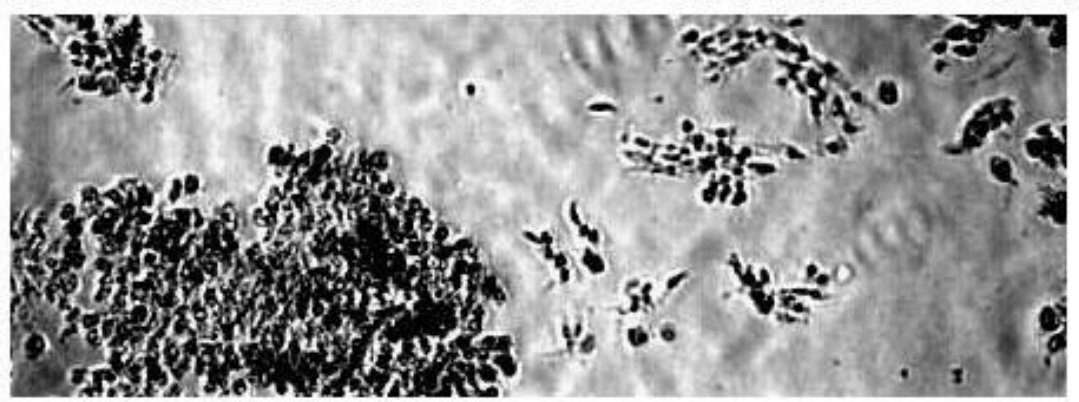

Figure 6. Light micrographs (phase contrast) of mouse myoblast cell line (C2C12) after 8 hours of incubation with 10, 20, and $50 \mu \mathrm{g} / \mathrm{ml}$ of Egyptian cobra (Naja haje) venom in serum free medium (SFM) at $37^{\circ}$ C. (X 400).

A: Control long myotubes crossing the field, and the cell membrane is smooth without irregularities. Some fibroblasts are present.

B: Cells incubated with $10 \mu \mathrm{g} / \mathrm{ml}$ dose. Note the presence of few vacuoles (V) and cells with rounded and oval appearance rather than the normal elongated configuration (black arrows).

C: Cells incubated with $20 \mu \mathrm{g} / \mathrm{ml}$ dose, higher number of cells showing rounded and oval appearance (black arrows) with dense accumulated contents and very few cells with their fibroblastic common appearance. Higher number of vacuoles (V) in the culture.

D: Cells incubated with the highest dose $(50 \mu \mathrm{g} / \mathrm{ml})$ of cobra venom. Most of the cells died. 
M. A. A. Omran et al. BIOCHEMICAL AND MORPHOLOGICAL ANALYSIS OF CELL DEATH INDUCED BY EGYPTIAN COBRA (Naja haje) VENOM ON CULTURED CELLS. J. Venom. Anim. Toxins incl. Trop. Dis., 2004, 10, 3, p.234.
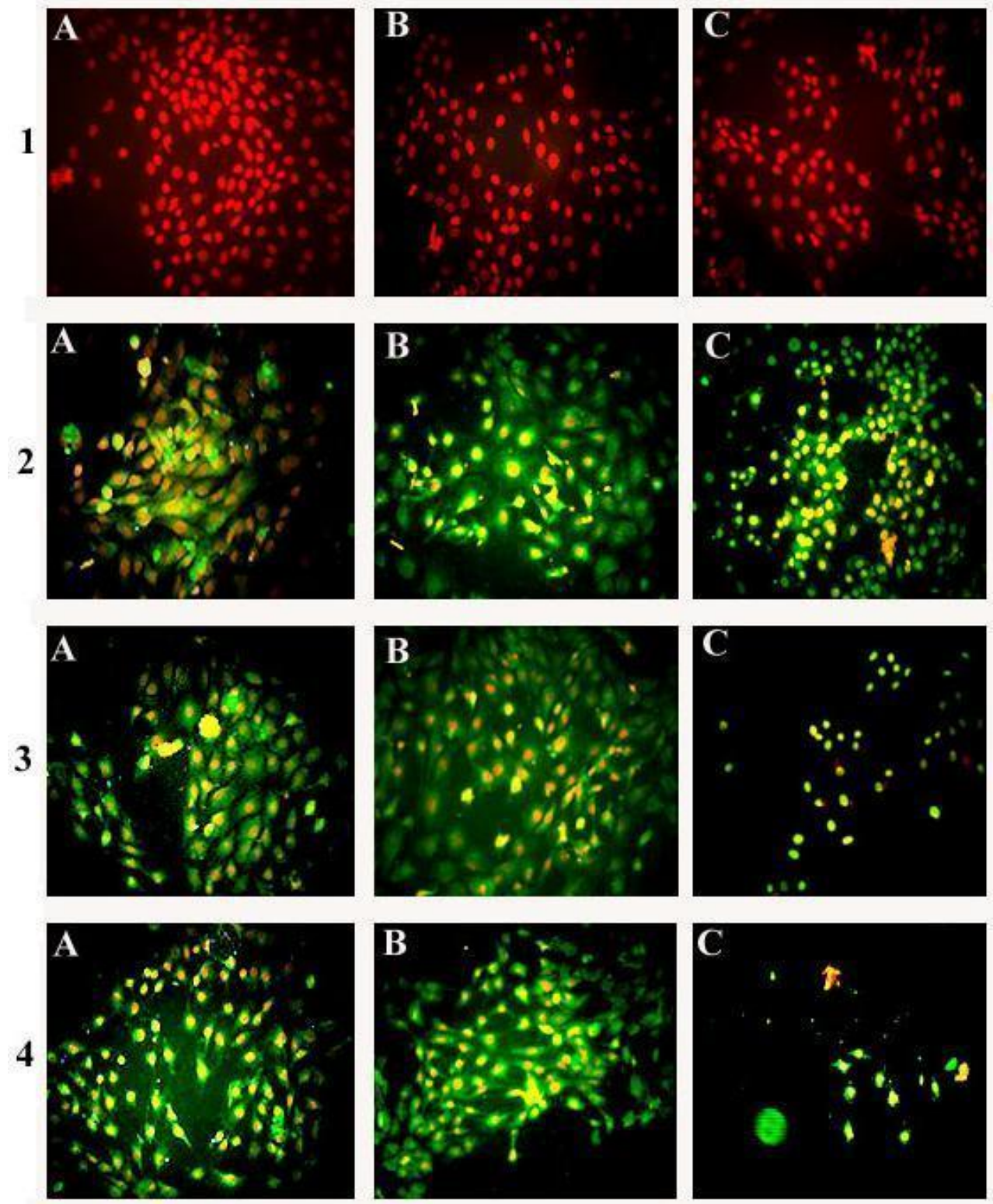

Figure 7. Representative photomicrographs showing labelling of DNA strand breaks associated with apoptosis assayed by TUNEL, using the Apoptosis Detection system, Fluorescein, in presence of TdT enzyme. Cell lines were grown on lab-Tek chamber slides and treated with 10,20 , and $50 \mu \mathrm{g} / \mathrm{ml}$ of Egyptian cobra (Naja haje) venom. Slides were incubated for 1, 2, 4, and 8 hours in serum free medium (SFM) at $37^{\circ} \mathrm{C}$. After the treatment, the slides were washed twice with PBS and analysed. Note the DNA fragmentation, as evidenced by Fluorescein-12-dUTP incorporation (yellow-green fluorescence), indicative of apoptosis (panels 2, 3, and 4). Panel 1, shows the red fluorescent of propidium iodide staining nonapoptotic cells. (X 400).

$1=$ untreated control cells;

$2=$ Cells incubated with $10 \mu \mathrm{g} / \mathrm{ml}$ of cobra venom.

$3=$ Cells incubated with $20 \mu \mathrm{g} / \mathrm{ml}$ of cobra venom.

4= Cells incubated with $50 \mu \mathrm{g} / \mathrm{ml}$ of cobra venom.

$\mathrm{A}=$ After 2 hours

$\mathrm{B}=$ After 4 hours

$\mathrm{C}=$ After 8 hours. 
M. A. A. Omran et al. BIOCHEMICAL AND MORPHOLOGICAL ANALYSIS OF CELL DEATH INDUCED BY EGYPTIAN COBRA (Naja haje) VENOM ON CULTURED CELLS. J. Venom. Anim. Toxins incl. Trop. Dis., 2004, 10, 3, p.235.
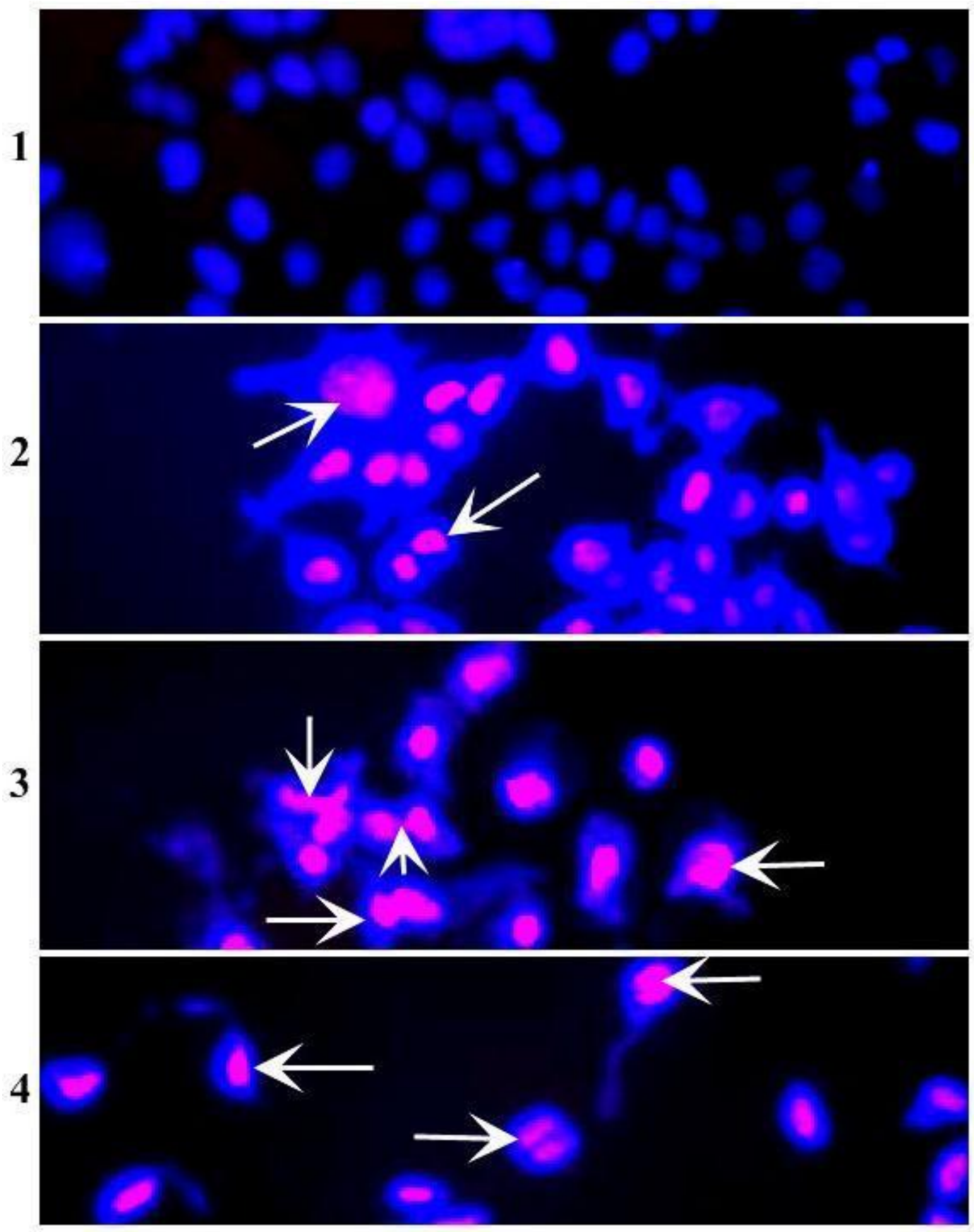

Figure 8: Representative photomicrographs showing 293T cells DAPI staining after 4 hours of incubation with Egyptian cobra (Naja haje) venom. Cells were prepared and treated as described in Figure 7. Slides were stained with DAPI (dilution 1:1000 in PBS) for 10 minutes in the dark at $0-5^{\circ} \mathrm{C}$. Apoptosis reveals several characteristic morphological changes, such as chromatin condensation and nuclear fragmentation (arrows) with fluorescent blue cytoplasm and pink to red nucleus. (X 400).

$1=$ Untreated control cells;

$2=$ Cells incubated with $10 \mu \mathrm{g} / \mathrm{ml}$ of cobra venom.

$3=$ Cells incubated with $20 \mu \mathrm{g} / \mathrm{ml}$ of cobra venom.

$4=$ Cells incubated with $50 \mu \mathrm{g} / \mathrm{ml}$ of cobra venom. 
M. A. A. Omran et al. BIOCHEMICAL AND MORPHOLOGICAL ANALYSIS OF CELL DEATH INDUCED BY EGYPTIAN COBRA (Naja haje) VENOM ON CULTURED CELLS. J. Venom. Anim. Toxins incl. Trop. Dis., 2004, 10, 3, p.236.

\section{DISCUSSION}

Cell death is currently the subject of considerable researches. This interest stems, in part, from the potential of understanding the oncogenesis and from the possibility of exploiting cell death program for therapeutic purposes. Cell death has been considered to be a degenerative phenomenon, a summary of the cell metabolic activity (6). In 1982, Farber (7) suggested that, under certain conditions, cell death might not be a passive event, but rather the result of an active process, as the overproduction of “cell suicide” instead of “cell homicide” enzymes or proteins. Some snake venoms contain toxins that are reported to induce cell death in vivo $(14,21,27,29)$ and selectively damage certain types of cells, such as muscles $(2,28,40)$. In this work, we analyse the in vitro process of cell death caused by Egyptian cobra venom on two different cell lines, which may not only be useful to understand how cell death is triggered, but also provide means for eliminating unwanted cells, such as tumour cells.

Our data clearly demonstrated marked cytotoxic effects and acute cell injury produced by $N$. haje venom in the $293 \mathrm{~T}$ and C2C12 cell lines. The release of LDH and CK into the culture media, which gives an accurate measure of cellular toxicity induced by the venom, correlates well with the severity of cell death and membrane damage observed in this study. Mostly, these effects were time and dose-dependent in both cell lines. The in vitro release of the cytosolic enzymes, LDH and CK, proved to be a reliable test for cellular cytotoxicity, providing a measure of the cell membrane integrity and cell viability (2). Early release (within 30-60 min) of significantly high percentages of these enzymes, especially after incubation with the highest dose of venom and the concomitant swelling of some treated cells, as evidenced in the morphological examination, revealed the occurrence of necrosis. This phenomenon of cell death was more characteristic in the C2C12 cell line than in 293T cells treated with cobra venom. It has been reported that the first step in necrosis is a reversible swelling of the cells followed by plasma membrane failure and subsequent cell lyses liberating cellular compounds $(15,26)$. On the other hand, the apoptotic indices were higher in $293 \mathrm{~T}$ cells (up to 50\%) than in C2C12 cells (up to 38\%) incubated with different cobra venom concentrations for 8 hours. Apoptosis was evident by the increased number of TUNEL and DAPI-stained positive nuclei, chromatin condensation and DNA fragmentation, apoptosis characteristics that have been observed on numerous occasions $(5,9,13)$. It is important to 
M. A. A. Omran et al. BIOCHEMICAL AND MORPHOLOGICAL ANALYSIS OF CELL DEATH INDUCED BY EGYPTIAN COBRA (Naja haje) VENOM ON CULTURED CELLS. J. Venom. Anim. Toxins incl. Trop. Dis., 2004, 10, 3, p.237.

emphasize that process of cell death was prominent in 293T cells. Furthermore, the examination of both cultured cell lines after 8 hours of treatment with the highest venom dose (50 $\mu \mathrm{g} / \mathrm{ml}$ ) showed severely shrunken and damaged cells, to the extent that individual cells could not be identified.

There are many reports on the effect of snake venoms and myotoxins in the muscle tissue, but none had established whether it is a primary or secondary effect produced by intramuscular microthrombosis, anoxia, bleeding, and others. $(1,17,25)$. This investigation shows that the damage induced by Egyptian cobra venom on both cell lines is direct and not secondary to microcirculation disruption, which causes muscle necrosis in animals and human beings.

The conclusions obtained from this study indicate that cobra venom cause cell death by two different mechanisms: necrosis and induction of apoptosis. The apoptotic mechanism accompanied with cell necrosis was observed in both tested cell lines; however, necrosis was predominant in C2C12 cells, while apoptosis was more common in 293T cells. This unusual form of cell death induced by $N$. haje venom may represent a combination of apoptosis and necrosis within the same cell. It can be suggested that cell injury caused by the cytotoxic components of cobra venom activate a death program that leads to irreversible damage and necrotic effects on 293T and C2C12 cells. This form of cell death was recognized by Shimizu et al. (30) in mesangial cells treated with anti-Thy-1.1 antibody. The use of the crude venom in this in vitro cytotoxicity study suggests that, probably, the effects observed are neither due to the venom metabolites nor one of its fractions, but rather to the combined venom components. Although we did not ascertain the mechanism of this effect, it is possible that our results could be due to the variations in the venom toxic components and their sensitivity to different cell types.

This is a first-hand investigation showing the apoptotic effect of $N$. haje venom at the cellular level. Cell death induced by Egyptian cobra venom appears to be only partially associated with an apoptotic mechanism. The contribution of the apoptotic pathway may, however, be dependent on concentration and/or time of exposure to cobra venom. 
M. A. A. Omran et al. BIOCHEMICAL AND MORPHOLOGICAL ANALYSIS OF CELL DEATH INDUCED BY EGYPTIAN COBRA (Naja haje) VENOM ON CULTURED CELLS. J. Venom. Anim. Toxins incl. Trop. Dis., 2004, 10, 3, p.238.

\section{ACKNOWLEDGEMENTS}

The authors thank Prof. Tarek R. Rahmy, Zoology Department, Faculty of Science, Suez Canal University, Ismailia, Egypt, for his valuable comments.

\section{REFERENCES}

1 ARCE V., BRENES F., GUTIERREZ JM. Degenerative and regenerative changes in murine skeletal muscle after injection of venom from the snake Bothrops asper: a histochemical and immunocytochemical study. Int. J. Exp. Pathol., 1991, 72, 211-26.

2 BRUSES JL., CAPASO J., KATZ E., PILAR G. Specific in vitro biological activity of snake venom myotoxins. J. Neurochem., 1993, 60, 1030-42.

3 DEHESA-DAVILA M., ALAGON AC., POSSANI LD. Clinical toxicology of snakebite in Africa and the Middle East / Arabian Peninsula. In: MEIER J., WHITE J. Eds. Handbook of clinical toxicology of animal venoms and poisons. New York: CRC Press, 1995: 433-92.

4 EL-FIKY MA. Hyperglycemic effect of a neurotoxic fraction (F3) from Naja haje venom: role of hypothalamo-pituitary adrenal axis (HPA). J. Nat. Toxins, 1999, 8, 203-12.

5 ESSBAUER S., AHNE W. The epizootic haematopoietic necrosis virus (Iridoviridae) induces apoptosis in vitro. J. Vet. Med. B. Infect. Dis. Vet. Public Health, 2002, 49, 25-30.

6 FARBER E. Biochemical pathology. Annu. Rev. Pharmacol., 1971, 11, 71-96.

7 FARBER E. Chemical carcinogenesis: a biological perspective. Am. J. Pathol., 1982, 106, 271-96.

8 GORCZYCA W., GONG J., ARDELT B., TRAGANOS F., DARZYNKIEWICZ Z. The cell cycle related differences in susceptibility of HL-60 cells to apoptosis induced by various antitumor agents. Cancer Res., 1993, 53, 3186-92.

9 GRUBER MB., ANUSZEWSKA EL., SKIERSKI JS. Activation of programmed cell death (apoptosis) by adriamycin in human neoplastic cells. Mutat. Res., 2001, 484, 87-93. 
M. A. A. Omran et al. BIOCHEMICAL AND MORPHOLOGICAL ANALYSIS OF CELL DEATH INDUCED BY EGYPTIAN COBRA (Naja haje) VENOM ON CULTURED CELLS. J. Venom. Anim. Toxins incl. Trop. Dis., 2004, 10, 3, p.239.

10 HINES MD., ALLEN-HOFFMANN L. Analysis of DNA fragmentation in epidermal keratinocytes using the apoptosis detection system, fluorescein. Promega notes, 1996, 59, 30-7.

11 HOUCHINS JP. Immunotoxin-induced apoptosis. Stem Cells, 2000, 18, 348-5.

12 IMAM AH., RAHMY TR. Reactive astrocytic response and increased proliferatic cell nuclear antigen expression in cerebral cortex of envenomated rats. J. Toxicol. Toxin Rev., 2001, 20, 245-59.

13 LAMBOLEY C., BRINGUIER AF., FELDMANN G. Induction of apoptosis in normal cultured rat hepatocytes and in Hep3B, a human hepatoma cell line. Cell Biol. Toxicol., 2000, 16, 185-200.

14 LIPPS BV. Decreased levels of nerve growth factor in organs of mice as a consequence of sub-lethal injection of cobra venom. J. Nat. Toxins, 2001, 10, 283-90

15 LYONEL GI., ESTHER DI. Apoptosis. Stem cells, 1999, 17, 306-13.

16 MARISTELA P., DANIELA DC., ANTONIO RG., DELWOOD CC. The effect of lectin from the venom of snake, Bothrops jararacussu, on tumor cell proliferation.

Anticancer Res., 1999, 19, 4023-6.

17 MEBS D., OWNBY CL. Myotoxic components of snake venoms: their biochemical and biological activities. Pharmacol. Ther, 1990, 48, 223-36.

18 MEIER J., THEAKSTON RDG. Approximate LD50 determination of snake venoms using eight to ten experimental animals. Toxicon, 1986, 24, 395-401.

19 MOHAMED AH., HANNA MM. The in vivo anticoagulant effects of Naja venom. Toxicon, 1973, 11, 419-23.

20 MORAVEC R., RISS T. Assay system for detecting apoptosis and cell death. Promega notes, 1998, 68, 13-8.

21 MUKHERJEE AK., MAITY CR. Biochemical composition, lethality and pathophysiology of venom from two cobras- Naja naja and N. kaouthia. Comp. Biochem. Physiol. B Biochem. Mol. Biol., 2002, 13, 125-32. 
M. A. A. Omran et al. BIOCHEMICAL AND MORPHOLOGICAL ANALYSIS OF CELL DEATH INDUCED BY EGYPTIAN COBRA (Naja haje) VENOM ON CULTURED CELLS. J. Venom. Anim. Toxins incl. Trop. Dis., 2004, 10, 3, p.240.

22 OMRAN MAA. Monitoring of the electrocardiographic disorders of rat after administration of sublethal doses of Egyptian snake (cobra) venom. J. Nat. Toxins, 1997, 6, 261-74.

23 OMRAN MAA., ABDEL-NABI IM. Changes in the normal ECG parametrs and arterial blood pressure of rat after envenomation with Egyptian cobra (Naja haje) venom. Hum. Exp. Toxicol., 1997, 16, 327-33.

24 OMRAN MAA., ABDEL-NABI IM., EL-NAGAR MH. Serum biochemical and hormonal parameters as biomarkers for the toxic effects of Egyptian cobra (Naja haje) envenomation. J. Nat. Toxins, 1997, 6, 69-83.

25 OWNBY CL., COLLBERG TR. Characterization of the biological and immunological properties of fractions of prairie rattlesnake (Crotalus viridis viridis) venom. Toxicon, 1987, 25, 1329-42.

26 RAFF MC. Social controls on cell survival and cell death. Nature, 1992, 356, 397-400. 27 RAHMY TR., HEMMAID KZ. Histological and histochemical alterations in the liver following intramuscular injection with a sublethal dose of the Egyptian cobra venom.

J. Nat. Toxins, 2000, 9, 21-32

28 RAHMY TR., RAMADAN RA., FARID TM., EL-ASMAR MF. Actions of cobra venom on cardiac muscles of rats. J. Egypt. Ger. Soc. Zool., 1995a, 17 (C), 235.

29 RAHMY TR., RAMADAN RA., FARID TM., EL-ASMAR MF. Renal lesions induced by cobra envenomation. J. Egypt. Ger. Soc. Zool., 1995b, 17 (C), 251.

30 SHIMIZU A., MASUDA Y., KITAMURA H., ISHIZAKI M., OHASHI R., SUGISAKI Y., YAMANAKA N. Complement-mediated killing of mesangial cells in experimental glomerulonephritis: cell death by a combination of apoptosis and necrosis. Nephron, 2000, 86, 152-60.

31 SYLVIE M., LEYBAERT L., KATHARINA D. First and second messenger role of calcium: Survival versus apoptosis in serum-free cultured granulosa explants. Ann. N. Y. Acad. Sci., 2000, 926,101-15 
M. A. A. Omran et al. BIOCHEMICAL AND MORPHOLOGICAL ANALYSIS OF CELL DEATH INDUCED BY EGYPTIAN COBRA (Naja haje) VENOM ON CULTURED CELLS. J. Venom. Anim. Toxins incl. Trop. Dis., 2004, 10, 3, p.241.

32 SZASZ G., GRUBER W., BERNT E. Creatin kinase in serum. I. Determination of optimum conditions. Clin. Chem., 1976, 22, 650.

33 TU AT. Venoms: chemistry and molecular biology. New York: Wiley, 1977. 560p.

34 TU AT. Tissue damaging effects by snake venom. Hemorrage and myonecrosis. In: Handbook of natural toxins. New York: Marcel Dekker, 1991: 297.

35 WAHLFORS JJ., ZULLO SA., LOIMAS S., NELSON DM., MORGAN RA. Evaluation of recombinant alphaviruses as vectors in gene therapy. Gene Ther., 2000, 7, 47280.

36 WANG Y., JING L., XU K. A unique approach for high level expression and production of a recombinant cobra neurotoxin in Escherichia coli. J. Biotechnol., 2002, 94, 235-44.

37 WARRELL DA. Clinical toxicology of scorpion stings. In: MEIER J., WHITE J. Eds. Handbook of clinical toxicology of animal venoms and poisons. New York: CRC Press, 1995: 221-38.

38 WARREL DA., GREENWOOD BM., DAVIDSON NM., ORMEROD LD., PRENTICE CRM. Necrosis, haemorrhage and complement depletion following bites by the spitting cobra (Naja nigricollis). Q. J. Med., 1976, 45, 1-22.

39 YAFFE D., SAXEL O. Serial passaging and differentiation of myogenic cells isolated from dystrophic mouse muscle. Nature, 1977, 270, 725-7.

40 ZHANG C., GOPALAKRISHNAKONE P. Histopathological studies of the acute inflammation in synovial tissue of rat knee joint following intra-articular injection of PLA2 from Chinese cobra (Naja naja atra) venom. Toxicon, 1999, 37, 783-99. 